\section{Commentary: Neochord integrity: More than just initial breaking strength}

\author{
William M. DeCampli, MD, PhD
}

\begin{abstract}
Marin-Cuartas and colleagues ${ }^{2}$ measured the rupture force of expanded polytetrafluoroethylene neochords in vitro. They constructed 2 plastic hoops through which sutures were passed either as a series of interrupted sutures, a running suture line, or via the loop technique to simulate neochord mitral repair techniques. They tested several calibers (CV-3 through CV-6). They determined breaking strength of each arrangement. They found that rupture force varied from 26 to 328 Newtons with larger values associated primarily with larger caliber, but also with the running technique, and with a greater number of chords. The breaking strength of all arrangements far exceeded the known forces imposed on mitral chords by the contracting ventricle; that is, 0.1 to a few Newtons. This is consistent with the fact (known for decades) that a single strand of expanded polytetrafluoroethylene (caliber $>\mathrm{CV}-6$ ) meets this characteristic. ${ }^{3}$ Given that, the authors speculated that the value of acute breaking strength would somehow predict eventual suture degradation and perhaps rupture. In fact, based on their results they implied that the running technique was perhaps the "best performing" recommended technique.

There is certainly evidence that suture caliber may predict late rupture risk. In a study by Mutsuga and colleagues, ${ }^{4} 7$ of 304 patients required reoperation due to ruptured chords at times ranging from 44 to 201 months after initial placement. In these patients, 15 of $820(1.8 \%)$
\end{abstract}

\footnotetext{
From the Department of Clinical Sciences, The University of Central Florida College of Medicine and Division of Cardiovascular Surgery, Arnold Palmer Hospital for Children, Orlando, Fla

Disclosures: The author reported no conflicts of interest.

The Journal policy requires editors and reviewers to disclose conflicts of interest and to decline handling or reviewing manuscripts for which they may have a conflict of interest. The editors and reviewers of this article have no conflicts of interest.

Received for publication Aug 4, 2021; revisions received Aug 4, 2021; accepted for publication Aug 6, 2021; available ahead of print Aug 26, 2021.

Address for reprints: William M. DeCampli, MD, PhD, Division of Cardiovascular Surgery, The Heart Center, Arnold Palmer Hospital for Children, 83 W Miller St, Orlando, FL 32813 (E-mail: William.decampli@orlandohealth.com).

JTCVS Open 2021;8:276-7

2666-2736

Copyright (C) 2021 The Author(s). Published by Elsevier Inc. on behalf of The American Association for Thoracic Surgery. This is an open access article under the CC BY-NC-ND license (http://creativecommons.org/licenses/by-nc-nd/4.0/).

https://doi.org/10.1016/j.xjon.2021.08.007
}
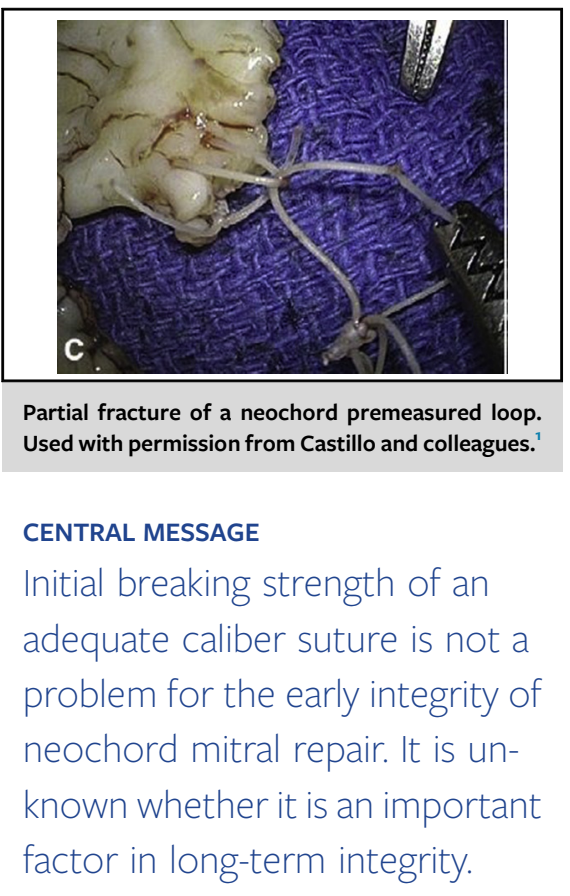

CV-5 neochords placed ruptured, but only 1 of 640 $(0.2 \%) \mathrm{CV}-4$ neochords placed ruptured. The rupture point was in the midportion in 13 chords, and near the leaflet in 3 chords. Evidence that different suturing arrangements (as described in the accompanying article and other than suture caliber) differ in durability due to differences in initial breaking strength is lacking. The mechanical relationship between acute (ie, initial) breaking strength and ultimate integrity of suture is complex. Gradual changes in the microstructure of the material due to chronic nonsteady loading and to porosity-related infiltration of biomolecules, minerals and cells may dominantly determine ultimate integrity rather than initial breaking strength itself. Knot configuration, initial forceps trauma, suboptimal suture length tuning, and the anchor point of the neochord (apical vs papillary muscle head) may influence the rate of weakening of the suture due to chronic elevated mean and peak tension (apical anchor point) or focal sites of increased stress. (Ask any fisherman where the line usually breaks!). Many of these factors have been examined in detailed computational (finite element) and benchtop simulator studies, including 1 by the current authors. ${ }^{5-7}$ What is really needed is an analysis of the mechanics of a cohort of neochord-repaired mitral valves (preferably serially) with follow-up long enough to determine the durability of the chords and, of course, the maintenance of valve competence-enough to begin to understand the underlying mechanical causes of failure. The good news is that in 
multiple clinical studies, the incidence of neochord rupture itself requiring reoperation is very low. ${ }^{8}$ (Panos and colleagues $^{9}$ followed 426 consecutive patients for 3 to 60 months who had undergone neochordal repair and found zero incidence of neochord rupture.) It's in our nature, however, to continue to make good even better.

\section{References}

1. Castillo JG, Anyanwu AC, El-Eshmawi A, Gordon RE, Adams DH. Early rupture of an expanded polytetrafluoroethylene neochord after complex mitral valve repair: an electron microscopic analysis. J Thorac Cardiovasc Surg. 2013;145: e29-31.

2. Marin-Cuartas M, Imbrie-Moore AM, Zhu Y, Park MH, Wilkerson R, Leipzig M, et al. Biomechanical engineering analysis of commonly utilized mitral neochordae. J Thorac Cardiovasc Surg Open. 2021;8:263-75.

3. Von Fraunhofer JA, Storey RJ, Masterson BJ. Tensile properties of suture materials. Biomaterials. 1988;9:324-7.
4. Mutsuga M, Narita Y, Tokuda Y, Uchida W, Ito H, Terazawa S, et al. Predictors of failure of mitral valve repair using artificial chordae. Ann Thorac Surg. May 19, 2021 [Epub ahead of print].

5. Sturla F, Votta E, Onorati F, Pechlivanidis K, Papparlardo OA, Gottin L, et al. Biomechanical drawbacks of different techniques of mitral neochordal implantation: when an apparently optimal repair can fail. J Thorac Cardiovasc Surg. 2015; 150:1303-12.

6. Paulson MJ, Imbrie-Moore AM, Wang J, Bae JH, Hironaka CE, Farry JM, et al Mitral chordae tendineae force profile characterization using a posterior ventricular anchoring neochordal repair model for mitral regurgitation in a threedimensional-printed ex vivo left heart simulator. Euro J Cardiothorac Surg. 2020;57:535-44.

7. Caballero A, McKay R, Sun W. Computer simulations of transapical mitral valve repair with neochordae implantation: clinical implications. J Thorac Cardiovasc Surg Open. 2020;3:27-44.

8. Bozso S, Shan SD, Nagendran J. Is there a problem with respect? Risk of neochordal rupture. Curr Opin Cardiol. 2020;35:101-6.

9. Panos A, Vlad S, Milas F, Myers PO. Is minimally invasive mitral valve repair with artificial chords reproducible and applicable in routine surgery? Interact Cardiovasc Thorac Surg. 2015;20:707-11. 